\title{
Government Enterepreneurial Intervention and Growth of Micro, Small and Medium Youth Enterprises in Kisii County, Kenya
}

\author{
Evelyn Nyachae Bosire*, Prof. Willy Muturi \\ JKUAT, Kenya
}

*Corresponding Author: Evelyn Nyachae Bosire, JKUAT, Kenya

\begin{abstract}
Even though micro, small and medium enterprises create many job opportunities, studies confirm that most micro and small enterprises die within 5 years, Gallup (2014). With this challenge in mind, coupled with other challenges such as inadequate capital, poor infrastructure, inadequate knowledge and skills, limited market access and rapid changes in technology, Government interventions are critical in supporting this sector. The purpose of the study was to assess the effect of government entrepreneurial interventions on the growth of micro, small and medium youth enterprises. Specifically, the study sought to establish the effect of training, funding, government policy and marketing as entrepreneurial interventions on the growth of MSMYEs Kenya. The study targeted a population of 1262 youth led micro and small and medium enterprises registered by the ministry of youth and sports in Kisii County. The County was then stratified according to the 9 administrative constituencies. A random sample of 304 Micro, small and medium enterprises was picked which are owned by youth in Kisii County drawn from each of the stratum. A descriptive research design combined with quantitative research approach was used to guide the study. Quantitative data was collected through the use of closed ended questionnaires. The questionnaires were delivered to the respondents personally by research assistants who were to wait for the questionnaire to be filled. Data analysis was done using Statistical Package for Social Sciences (SPSS) version 21. A multiple regression analysis was used to establish a model between growth of the enterprises and the government entrepreneurial interventions. The findings revealed that government funding, entrepreneurial training, marketing and government policies affected growth of youth owned micro, small and medium enterprises. The study concluded that most youth had limited or no access to government funding, training, involvement in policy making and marketing support thus their enterprises failed to grow. The study recommended that here is need for the government to ensure equitable and effective access to funding, markets and training among the youth so as to enhance growth of their enterprises.
\end{abstract}

Keywords: Government entrepreneurial intervention, training, funding, marketing, policies, youth enterprises

\section{INTRODUCTION}

\subsection{Background of the Study}

Micro, small and medium enterprises (MSMEs) growth have attracted considerable attention of both public and private sectors in recent past especially in the emerging nations as they are considered and recognized as critical pillars of socioeconomic transformation of any economy. A considerable number of counties have made provisions for policies that are deemed to promote their development plans, policies and programs for the promotion of SMEs. This is because of their perceived benefits to economic development including employment generation in rural areas economic transformation stimulation of indigenous entrepreneurship, reverse of urban rural migration, greater utilization of local raw materials, promotion of local technology mobilization of local savings, linkages balance by spreading investment more evenly ability to profitability in very narrow markets with low purchasing power among others (Jibrilla, 2013). According to Kondaiah (2010), MSMEsareamong the surest avenue for providing goods and services in rural or semi urban areas. The role of MSMEs is evident among the cottage businesses in many countries of the world such as Malaysia, Japan, South Korea, Zambia, and India among others. As a result, it is widely acknowledged as the springboard for sustainable economic development (Olajide, 2012).

Government plays a critical role entrepreneurial interventions for this study will encompass entrepreneurship training, funding opportunities, policies and marketing interventions on micro and 
small and medium youth enterprises. Micro, small and medium youth enterprises (MSMYEs) are therefore widely acknowledged asa vital sector of any economy, particularly because it creates a better opportunity for job creation (Momanyi, 2017). The United Nations Conference on Trade and Development (UNCTAD) (2015) confirms that there is increasing consensus that entrepreneurship plays a critical role on sustainable development and critical to gender equality, poverty reduction, and environmental sustainability. Despite their undisputed importance, past statistical evidence indicate that 3 out of 5 businesses fail within the first few months and those that continue 80 per cent fail before the fifth year (Kenya National Bureau of Statistics, 2007).

While Micro, small and medium youth enterprises are supported by Government, studies confirm that most enterprises die within 5 years, Gallup (2014). The high failure rate suggests that the sector fails to effectively manage the changes that they face in the midst of the dynamic business environment among other challenges that they find themselves into (Collagham\&Vener2011; Lots\& Vander, 2013). With this challenge in mind, coupled with other challenges such as inadequate capital, poor infrastructure, inadequate knowledge and skills, limited market access and rapid changes in technology, government interventions are critical in supporting this sector. The National Bureau of Statistics (2016) confirms that about 2.2 million MSMYEs were closed in the rural areas as compared to 1 million established in the urban areas.

There exists consensus among scholars that youth entrepreneurship can play a critical role in job creation among the youth (UNCTAD, 2015). A survey carried out by Geo Poll 2017, confirms that unemployment poses the highest threat to the future of the youth because it breeds crime, violence, drug abuse and other social charges (Kwonyike, 2017). Therefore, government needs to support the micro and small youth enterprises in Kenya, through interventions that provide proper legislative framework on MSMYEs, facilitate access to the markets, and provide funding opportunities among other interventions. Still despite these initiatives, SMEs still have a low survival rate with serious challenges leading to 60\% failure within the first three years of operation (Sharu, 2013). Kiveu (2013) observed that Kenyan SMEs are ill prepared to compete in global markets and that fewer of them are capable of venturing into the export market. However, a questions still remains on whether these interventions lead to a sustainable growth of the MSMYEs in Kenya.

In order to effectively target youth enterprises and activities, the constitution of Kenya (2010) defines a youth as young person's between the ages of 18- 35. Based on this definition, the study will focus on the youth within this age brackets who own startup or a micro, small and medium enterprise in Kenya (Oseifuah, 2010). GEM report (2012) describes youth entrepreneurship as an additional way of allowing youth into the labor market and promoting job creation using the existing support structures aimed at developing entrepreneurship particularly micro, small and medium enterprises (MSME) sector which exist in various countries including Kenya. According to the SME Act 2012 of Kenya which describes, micro enterprises as business organizations with a maximum annual turnover of KES 500,000 employing less than 10 people, whereas small enterprises have an annual turnover of KES 500,000 and 5 million with employment capacity of 10-49 people and medium enterprises.

Akwalu (2014) argues that although there has been a growing trend in promoting youth owned enterprises in Kenya, not much has been achieved. Most of the promotions have been through the affirmative action such as Youth Enterprise Development Fund (YEDF) started in 2007 to provide access to funds to registered youth groups to start and develop enterprises, Uwezo fund created through the 2013/2014 financial budget which set out an ambitious youth and women empowerment programme by allocating 6 billion as revolving fund to be loaned to the youths and women. Through the initiative, the government also rolled out a policy to provide 30 percent of all government procurement to the youth and women as well as persons with disabilities (GOK, 2013). Other programs to support youth entrepreneurship especially micro and small youth enterprises in Kenya includes the Vision 2030 where specific youth development programmes are emphasized to promote access to business enterprise funds, skills training, and business development services among others.

Kisii County has a youthful population estimated at 385,143 in 2012 which represents $31.4 \%$ of the total county population. According to the Kenya Bureau of statistics (2012) sixty-one per cent (61\%) of the unemployed people in the county are the youth. The population is expected to rise to 437,692 and 518,774 in 2015 and 2017 respectfully. Due to this challenge, the county government is expected to implement projects and programmes that will address unemployment including, capacity building 
through training and development, enhance access to finance by the youth, enact youth friendly legislation and assist in marketing youth products among other entrepreneurship interventions to enable the youth effectively contribute to the socio-economic development of the county. The county is characterized by high potential of both agricultural and non-agricultural activities as well as multiple of small and medium businesses.

\subsection{Statement of the Problem}

While SMEs remain critical to the country's economy through job creation and the overall contribution to the tax revenue, their growth and survival rate has been minimal with six (6) out of ten (10) enterprises closing their operations within their first year of operation. A report by the Kenya National Bureau of Statistics (KNBS) revealed that over $40 \%$ of the SMEs are youth owned and they are among the most SMEs that do not make it to their second birthday (KNBS, 2017). This shows a matter of concern in which the Youth are over $60 \%$ of the country's population (Kenya National Census, 2019) and make up to $70 \%$ of the unemployed population. In a country where the unemployment rate is close to $10 \%$, entrepreneurship is the only solution that can assure job creation and create more opportunities for others (Ismail, 2018).

The Kenyan government in a bid to enhance entrepreneurship and promote employment and economic growth, it has laid out several entrepreneurship support programmes including funding, training and mentorship (GoK, 2017). Despite these interventions, there is little improvement to be seen among the SMEs as far as growth is concerned. While previous studies have focused on growth of SMEs and how it is affected by aspects such as funding, training and policies, there is very little literature available on the government interventions and growth of youth owned MSMEs. This study therefore seeks to fill the existing methodological, conceptual and contextual gaps by assessing the effect of government entrepreneurial interventions on growth of youth owned MSMYEs in Kenya.

\subsection{Objectives}

(i) To establish the effect of training on growth of Micro, Small and Medium Youth Enterprises in Kenya.

(ii) To determine the effect of funding on growth of Micro, Small and Medium Youth Enterprises in Kenya.

(iii)To assess the effect of government policy on growth of Micro, Small and Medium Youth Enterprises in Kenya.

(iv)To examine the effect of marketing on growth of Micro, Small and Medium Youth Enterprises in Kenya.

\section{LITERATURE REVIEW}

\subsection{Theoretical Framework}

\subsubsection{The Keynesian Theory}

Keynesian economics advocates a mixed economy, predominantly private sector, but with a large role of government and public sector (Osadede, 2007). Keynesian economists often argue that private sector decisions sometimes lead to inefficient macroeconomic outcomes which require active policy responses by the public sector, in particular, monetary policy actions by the central bank and fiscal policy actions by the government, in order to stabilize output over the business cycle. The Keynesian theory offers useful insight to the understanding of the impact of government entrepreneurial intervention on the growth of youth owned SMEs. The relevance of this theory is its ability to provide the basis for government in economic activities through various private enterprise incentives and development (Ogechukwu, 2011).

\subsubsection{Economic Entrepreneurship Theory}

The theory ignores the nature of entrepreneurial activity and down plays the diverse contexts in which entrepreneurship occurs. The economic system consists of exchange participants, exchange occurrences, and the impact of results of the exchange on other market actors. Entrepreneurship is a very important criterion for economic development. Although achievements in organizations are credited to the organization, they still find their basis in individual initiatives and motivation. The theory therefore is limited to understanding of the role played by individuals in entrepreneurship (Amolo, 2014). 


\subsubsection{Resource-Based View}

The Resource-based theory argues that access to resources by founders is an important predictor of opportunity based new venture growth (Alvarez \&Busenitz, 2001). The theory therefore offers a theoretical explanation on the importance of various types of resources among micro, small and medium business enterprises which drive their overall competitiveness and performance. It posits that firms can achieve and sustain their competitive advantage if they have tangible or intangible resources that are valuable, rare, inimitable and non-substitutable. This theory stresses the importance of financial, social and human resources. Thus, access to resources enhances the individual's business to detect and act upon discovered opportunities (Davidson \& Honing, 2003).

\subsection{Empirical Literature Review}

Sitoula (2015) did a study on the challenges and prospects of youth entrepreneurship in Kathmandu adopting descriptive research design sampled 100 youth entrepreneurs from a population of 150 entrepreneurship businesses formally registered in the region. The study established that there are obstacles that hinder young entrepreneurs in setting up businesses and subsequently managing them in Kathmandu in Nepal.

Eric (2015) studied the effectiveness of government intervention in the SME sector in Brussels. The study sampled 162 beneficiaries of government financial support to promote SMEs which represented about $38 \%$ of total direct financial support to business enterprises in Brussels. It was observed that government subsidies on SMEs contributed greatly to their performance, followed by loans and equity capital provided by the government. Simona (2015) assessed the role government intervention inform of subsidies in the growth of SMEs in less developed countries. The study found a positive correlation between receipt of public subsidies and the innovative activities of SMEs in developing economies.

Aliyu (2013) studied the impact of government interventions on Small Scale enterprise in Mubi North local government Area in Nigeria. The study observed that business operators had poor perception on government interventions to promote small enterprises, at the same time very few small business operators were aware and able to access the benefits of government interventions in the operation of small enterprises. Atsu (2014) studied the role of Government in the development of MSMES in Nigeria. The study revealed that there was a strong relationship between government interventions measures such as improvement of infrastructure, capacity building and provision of financial support on their development. Sambo (2016) studied the factors affecting youth entrepreneurship development in Kibera sub County, Kenya. The study observed that the Kenyan government had put in place policies and programs that facilitates access to credit by youth owned SMEs. The study recommended a similar study to be conducted in other parts of the country.

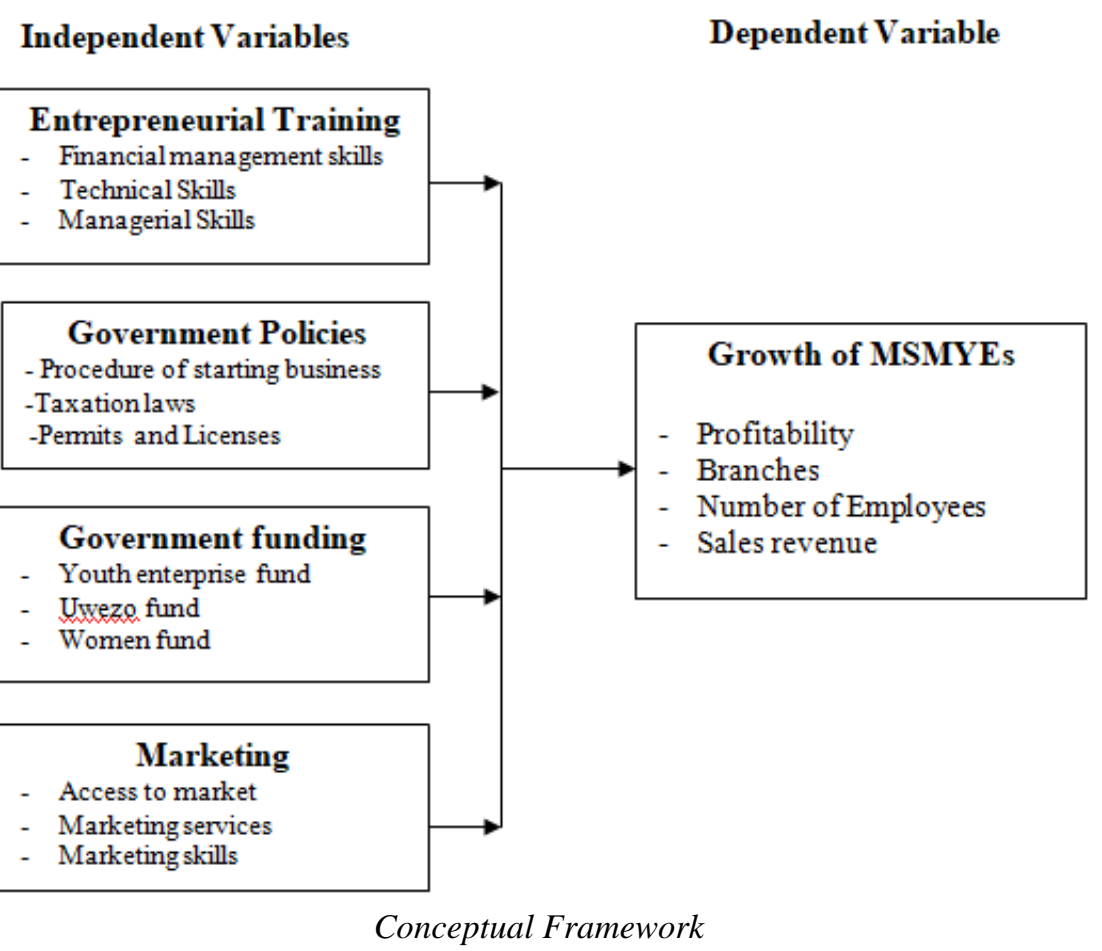




\section{RESEARCH METHODOLOGY}

The study employed a descriptive research design. The target population comprised of youth owned MSMEs in Kisii County. The data available from the Ministry of Sports and Youth Kisii County (2017) reveal that there are 1262 registered MSMEs which are currently receiving entrepreneurial support from both the National government and Kisii county government. They access support from the Youth enterprise development fund, Uwezo fund and the Women Enterprise Development Fund. These youth enterprises are dispersed across the sub counties within the county. The population was conveniently divided into sub counties where the sample was apportioned according to the number of enterprises in each sub county. Using a sampling formula, a sample of 304 MSMEs were surveyed.

A structured questionnaire was used to collect data from the respondents and analyzed using SPSS.

A regression model was used to test for the hypotheses of the study as shown.

$\mathrm{Y}=\beta_{0}+\mathrm{B}_{1} \mathrm{X}_{1}+\mathrm{B}_{2} \mathrm{X}_{2}+\mathrm{B}_{3} \mathrm{X}_{3}+\mathrm{B}_{4} \mathrm{X}_{4}$

Where,

$\mathrm{Y}=$ Growth of MSMES

$\beta 0=$ constant (coefficient of intercept)

$\mathrm{X} 1=$ Government policy

$\mathrm{X} 2$ = Marketing

$\mathrm{X} 3=$ Access to Credit

$\mathrm{X} 4$ = Training and Development

\section{FINDINGS}

\subsection{Response Rate}

A response rate of $79 \%$ was obtained. This is where 240 respondents filled and gave back the questionnaires for analysis within the stipulated time. This was considered adequate for analysis where according to Young (2011), a response rate of between 50\% and 80\% is adequate for making conclusions and recommendations in a study.

\subsection{Descriptive Results}

\subsubsection{Entrepreneurial Training}

The study sought to find out the effect of training on growth of youth owned micro, small and medium enterprises. The findings revealed that majority of the respondents were of the view that training offered by the government and other stakeholders was key to enabling them make critical decisions and effectively run their enterprises into success. According to Goel and Rishi (2012), for SMEs to alleviate and eliminate poverty, the entrepreneurs ought to be trained on managerial skills and technical skills so as to effectively run their enterprises.

Table1. Descriptive Results on Training

\begin{tabular}{|l|l|l|}
\hline Statement & Mean & Std. Dev. \\
\hline I have attended training previously on entrepreneurship or business related aspects & 2.92 & 1.03 \\
\hline I have been trained on management skills to enable me run the business & 2.46 & 1.15 \\
\hline I have the technical skills require to run my daily operations in the business & 3.96 & 0.85 \\
\hline The training programmes by the government are accessible and effective & 2.92 & 1.03 \\
\hline
\end{tabular}

\subsubsection{Government Policies}

The study aimed at assessing the effect of government policies on growth of youth owned micro, small and medium enterprises. The findings as shown in Table 2 revealed that the policies by the government regarding MSMEs were not favourable to the enterprises and the youth entrepreneurs were not involved in formulation of the policies. This implies that the views of the youths were not adequately sought hence their consideration in the policies was minimal. De Mel, McKenzie and Woodruff (2014) argue that the policing is a key factor in enhancing the growth of Small enterprises in that they foster how well the operational effectiveness and regulations of the firms are aligned to mainstream growth and development. 
Government Enterepreneurial Intervention and Growth of Micro, Small and Medium Youth Enterprises in Kisii County, Kenya

Table2. Descriptive Results on Government Policies

\begin{tabular}{|l|l|l|}
\hline Statement & Mean & Std. Dev. \\
\hline $\begin{array}{l}\text { My opinions are sought when government policies affecting my enterprise are being } \\
\text { formulated }\end{array}$ & 2.99 & 1.06 \\
\hline I am aware of the recent policy requirements in operating the enterprise & 2.61 & 1.12 \\
\hline The laws on taxation and revenue collection are favourable to my enterprises & 3.30 & 0.98 \\
\hline The process for registration and licensing of new business is easy and effective & 2.94 & 1.36 \\
\hline $\begin{array}{l}\text { The laws regulating conduct of business by national government are consistent with } \\
\text { those of the county government }\end{array}$ & 2.31 & 1.18 \\
\hline
\end{tabular}

\subsubsection{Marketing}

The third objective of the study was to establish the effect of marketing on growth of youth owned micro, small and medium enterprises. The findings revealed that marketing was among the key missing factor affecting growth of the youth enterprises and the government had done very little to uphold marketing of the youth owned businesses' products and/or services. Kimando, Njogu and Kihoro (2012) contend that the marketing of the youth enterprises plays a significant role in enhancing the performance and growth of youth enterprises.

Table3. Descriptive Results on Marketing

\begin{tabular}{|l|l|l|}
\hline Statement & Mean & Std. Dev. \\
\hline $\begin{array}{l}\text { The government has created linkages with other organizations for marketing our } \\
\text { products }\end{array}$ & 2.77 & 0.97 \\
\hline The existing marketing infrastructure and network facilities supports our enterprises & 2.91 & 0.97 \\
\hline $\begin{array}{l}\text { The government has signed trade agreements with other countries to facilitate external } \\
\text { markets for our goods and services }\end{array}$ & 3.04 & 0.94 \\
\hline The government promotes access to market information for our enterprises & 3.17 & 0.94 \\
\hline $\begin{array}{l}\text { The government provides an opportunity for our enterprises to supply them with } \\
\text { goods and services }\end{array}$ & 2.09 & 1.28 \\
\hline
\end{tabular}

\subsubsection{Government Funding}

The study sought to establish the effect of government funding on growth of youth owned micro, small and medium enterprises. The results as shown in Table 4 revealed that the constraints in acquiring credit among the youth due to lack of collaterals and lack of proper and clear mechanisms of accessing the government funding affected the growth of youth owned enterprises. The findings are in line with those by Issa and Kiruthu (2019) who found that despite funding being a key factor in growth and performance of youth enterprises, many youth had limited access to the funding hence it did not play the intended purpose. The government funding should be equitable and aligned towards ensuring all the interested youth especially those with already running enterprises have a share so as to steer growth of their enterprises.

Table4. Descriptive Results on Funding

\begin{tabular}{|l|l|l|}
\hline Statement & Mean & Std. Dev. \\
\hline The government provides mechanisms to reduce constraints in acquiring credit & 3.09 & 0.97 \\
\hline There are minimal collateral requirement in accessing credit & 2.99 & 0.98 \\
\hline Commercial banks have friendly requirements to fund youth enterprises & 2.71 & 1.01 \\
\hline The government provides convenient loan facilities for youth enterprises & 2.38 & 1.41 \\
\hline $\begin{array}{l}\text { The government has provided tax incentives, debt financing schemes for youth } \\
\text { enterprises }\end{array}$ & 3.17 & 0.99 \\
\hline
\end{tabular}

\section{CONCLUSiON}

From the findings, it can be clinched that the government entrepreneurial interventions are critical to growth of youth owned micro, small and medium enterprises. The study however concludes that the training on technical and managerial skills has not been effectively carried out thus affecting the growth of youth enterprises. Moreover, the financing of the youth enterprises has been inadequate, inaccessible and little awareness has been created on how to access the fund among the youth. The study further concluded the policies on youth enterprises were not favourable and that the youth were not consulted during formulation of the policies. 


\section{RECOMMENDATIONS}

The study recommends that the government ought to ensure the interventions on entrepreneurship are youth-centred since these are the main critical in economic growth and make the biggest portion of the unemployment rate. The training should encompass on managerial skills, technical skills and strategic competence in order to steer the youth's ability to start and run the businesses into success. The government ought to create awareness on the available funding mechanisms and how to access the funding while ensuring the youths are also able to access the funding from other sources such as MFIs and commercial banks. The government should provide adequate marketing support to the youth enterprises through infrastructure and availing information on how to access the available markets for their products. When formulating policies that touch on the youth enterprises, the government should involve the youth by seeking their views and considering them in the final decision making.

\section{REFERENCES}

[1] Abouzeedan. B (2004): SME Performance and its Relationship to Innovation. Linköping Studiesin Science and Technology, Dissertation

[2] Akwalu, P. (2014). Factors Influencing Performance of Youth Owned Small and Medium Enterprises. A Case of Maara Sub-County; Tharaka-Nithi County; Kenya. Unpublished Masters Dissertation

[3] Aliyu A. (2013) Impact of Government Interventions on Small Scale Enterprises in Mubi North Local Government Area, Adamawa State, Nigeria. Journal of Economics and Sustainable Development

[4] Atsu, I. (2014) The Role of Government in the Development of MSMEs in Nigeria between 1991 and 2012.International Journal of Business and Social Research

[5] Awino S (2013) Small and Medium Enterprises and Devolved Government System: an Assessment of the Regulatory and Institutional Challenges Affecting the MSMEs Development in Kenya. CUTS Centre for International Trade Economics and Environment (CUTS CITEE) Nairobi, Kenya

[6] Ayozie. D (2013) Small and Medium Scale Enterprises (MSMES) in Nigeria the Marketing Interface. Global Journal of Management and Business Research Marketing.

[7] Bless, C., C. Higson-Smith, A. Kagee (2006). Fundamentals of social research methods: An African perspective, Juta and Company Ltd

[8] Bushell, B. (2008). "Women entrepreneurs in Nepal: what prevents them from leading the sector?" Gender $\&$ Development.

[9] Cheung, C. (2008). Entrepreneurship education in Hong Kong's secondary curriculum: possibilities and limitations. Education Training.

[10] Child, J. \& Lu, Y. (2012). Institutional constraints on economic reform: the case of investment decisions in China. Organization Science.

[11] Cooper, D. R., \& Schindler, P. S. (2006). Business research methods. New York: McGraw Hill.

[12] De Mel, S., McKenzie, D., \& Woodruff, C. (2014). Business training and female enterprise startup, growth, and dynamics: Experimental evidence from Sri Lanka. Journal of Development Economics, 106, 199-210.

[13] Eric G (2015) Optimal Effectiveness of Government Intervention in the SME Sector: Evidence from the Brussels Capital Region. International Centre for Innovation Technology and Education

[14] Etuk, E. J \&Mbat, D. O. (eds.) (2010).Entrepreneurship Development for Students and Practitioners. Abuja, Century Frontiers Investment Ltd

[15] Filmer, D. and Fox, L. (2014).Youth Employment in Sub-Saharan Africa. Africa Development Series, Washington, DC: World Bank. [Available online: http://documents.worldbank.org/curated/en/

[16] GEM. 2014. [Online]. Available at: http://www.gemconsortium.org. (Accessed: 15 September,

[17] Ghana Statistical Service (2012) the 2010 Population and Housing Census: Summary Report of Final Results. Accra: Sakoa Press Limited

[18] Goel, G., \& Rishi, M. (2012). Promoting entrepreneurship to alleviate poverty in India: An overview of government schemes, private-sector programs, and initiatives in the citizens' sector. Thunderbird International Business Review, 54(1), 45-57.

[19] Gullup (2014) Why So Many New Companies Fail During Their First Five Years. Retrieved from. gall up .com/business journal. 
[20] Hawksford (2017).Singapore Government Funding and assistance Schemes. IFAD, Promoting Rural Enterprise Growth and Development: Lessons from Four Projects in Sub-Saharan Africa, https:// www.ifad.org/documents.

[21] ILO (2008). "Global Employment Trends for Youth

[22] International Finance Corporation (2013). Closing the Credit Gap for Formal and Informal Micro, Small, and Medium Enterprises. Washington, D.C

[23] Investment, Enterprise and Development Commission. Seventh session

[24] Ismail, Z. (2018). Indicators and methods for assessing entrepreneurship training programmes (K4D Help Desk Report No. 321). University of Birmingham

[25] Issa, A. G. \& Kiruthu, F. (2019). Effect of youth enterprise development fund on the performance of youth enterprises in Marsabit County, Kenya. International Academic Journal of Law and Society, 1(2), 138-164

[26] Kamau (2013) Role of Youth Enterprise Development Fund on growth of Micro, small and medium enterprises focusing on Kiharu Consituency, Muranga County, Kenya

[27] Kelley, D. J., S. Singer and M. Herrington (2012). "The global entrepreneurship monitor." 2011 Global Report

[28] Kenya National Bureau of Statistics (2012).Population Census, 2009. Nairobi: Government printer.

[29] Kimando, L.N., Njogu, G.W. and Kihoro, J.M. (2012). Factors Affecting the Success of Youth Enterprise Development Funded Projects in Kenya; A Survey of Kigumo District Muranga County, International Journal of Business and Commerce, 1 (10), pp. 61-81.

[30] Kiveu, M.andOfafa, G. (2013). Enhancing market access in Kenyan MSMEs using ICT. Global Business and Economics Research Journal.

[31] Kluve et al., (2016) Interventions to Improve the Labour Market Outcomes of Youth: A

[32] KNBS(2016) Micro, Small And Medium Establishment (Msme) Survey

[33] Kothari, C. R. (2004). Research Methodology: Methods and Techniques (2nd ed.). Oxford: Oxford University Press.

[34] KPMG (2015) a new wave in India MMSMEs.An action agenda for growth. Retrieved from kpmg.com/in

[35] Mbogo, M. (2011). Influence of Managerial Accounting Skills on SME's on the Success and Growth of Small and Medium Enterprises in Kenya.Journal of language, Technology and Entrepreneurship in Africa.

[36] Mbugua, K., Njeri, A. (2014) Factors Affecting the Performance of Small and Micro Enterprises in Limuru Town Market of Kiambu County, Kenya. International Journal of Scientific and Research Publications

[37] Ministry of Industries (2016) National Industrial Policy-2016.Government of Bangladesh.

[38] Ministry of Trade, Industry and Cooperatives (2015) Uganda Micro, Small and Medium Enterprise (MSMEs) Policy. The Republic of Uganda

[39] Moronge , M ( 2016) Effects of County Government Policies on the Performance of Small and Medium Enterprise in Kenya: A Case of Kiambu County

[40] Njoroge, C. (2013) the effect of entrepreneurial education and training on the development of SMEs in Githunguri District, Kenya.

[41] Okoth, M (2013) Challenges of Financing Small \& Medium Enterprises [SMES] Inequity Bank Branches In Kenya. Unpublished MBA Thesis

[42] Onsomu.E (2014) State of Youth Unemployment in Kenya .Africa in focus

[43] Onwuegbuzie, A. J. and N. L. Leech (2005). "Taking the "Q" out of research: Teaching research methodology courses without the divide between quantitative and qualitative paradigms." Quality and Quantity.

[44] Oseifuah.K (2010)."Financial literacy and youth entrepreneurship in South Africa." African journal of Economic and management studies.

[45] Pagoso, C., Garcia, G., \& Guerrero de Leon, C (1992). Fundamental Statistics for College Students. Greenhills, Manila: Sinag -Tala Publishers

[46] Parthajeet, D. (2017) Micro, Small and Medium Enterprises(MSME) in India: Opportunities, Issues \& Challenges

[47] Policy Options for Institutional and Regulatory Reforms in Kenya (2013) MSMEs Development in the Devolved Governance System.Policy Brief 
[48] Rae, D. (2010), Universities and enterprise education: responding to the challenges of the new era, Journal of Small Business and Enterprise Development.

[49] Raposo, M. and Paço, A. (2011) "Entrepreneurship education: relationship between education and entrepreneurial activity", Psicothema.

[50] Republic of Kenya. (2013). Ministry of Economic planning report on MSMEs, Nairobi: Government Printers.

[51] Sambo, W. (2016). Factors affecting youth entrepreneurship development in Kibera district, Kenya. Problems and Perspectives in Management (open-access)

[52] Simona M (2015) Subsidies, financial constraints and firm innovative activities in developing

[53] Small Business Insight (2016). Why we can learn more from Brazil's SEBRAE', http://www. Small businessinsight.org/blog/why-we-can-learn-more-from- brazils-sebrae

[54] SMEDAN (2012). Survey Report on Micro, Small and Medium Enterprises (MSMEs) in Nigeria. Abuja, Small and Medium Enterprises Development Agency of Nigeria (SMEDAN)

[55] Systematic Review of Training, Entrepreneurship Promotion, Employment Services and Subsidized Employment Interventions, Campbell Systematic Reviews, the Campbell Collaboration.

[56] UNCTAD (2015) Promoting entrepreneurship for development. Trade and Development Board

[57] URT (2012). Micro Small and Medium Enterprises in Tanzania: National Baseline Survey Report

[58] Wood, M. S. (2011). A process model of academic entrepreneurship, Business. Horizons, 54(2):153-161

[59] World Bank Group, Enterprise Surveys Database, (2010). "World Business Environment Survey" (WBES) of more than 10,000 firms in 80 countries. Retrieved from http://www.enterprisesurveys.org

[60] Zindiye, S.(2012) The impact of Government and other Institutions' support on the Performance of Small and Medium Enterprises in the Manufacturing Sector in Harare, Zimbabwe. International journal for business management and economic research

\section{AUTHORS' BIOGRAPHY}

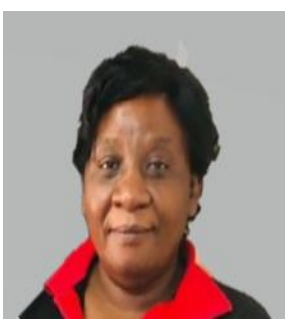

Evelyn NyachaeBosire, is a finalist $\mathrm{PhD}$ candidate at Jomo Kenyatta University of Agriculture and Technology. Evelyn holds a master's degree in entrepreneurship from Jomo Kenyatta University of Agriculture and Technology. Currently, she works at Kisii University, Kenya. Evelyn has a sturdy experience in entrepreneurship, management and marketing. She is a published author with interests in women and youth entrepreneurship, education management and marketing.

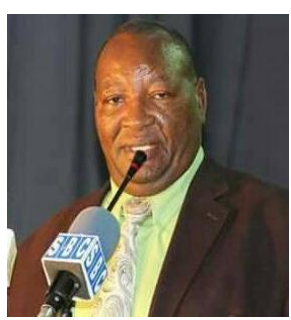

Professor Willy Muturi, is a holder of BA (First class honors), MA (Economics) both from the University of Nairobi and a $\mathrm{PhD}$ in Economics from Jomo Kenyatta University of Agriculture and Technology, Kenya. He is an Associate professor of Economics at Jomo Kenyatta University of Agriculture and Technology. He has been Associate dean of the School of Human Resource Development and Chairman of Economics Accounting and Finance department in JKUAT. He has a wide experience in research since 1990 when he was employed as a Research scientist at Kenya forestry research Institute. Since Joining JKUAT in 1992, he has supervised over 100 postgraduate students both at Masters and PhD levels and has more than 100 publications to his credit.

Citation: Evelyn NyachaeBosire \& Willy Muturi. "Government Enterepreneurial Intervention and Growth of Micro, Small and Medium Youth Enterprises in Kisii County, Kenya" International Journal of Managerial Studies and Research (IJMSR), vol 8, no. 12, 2020, pp. 55-63. doi: https://doi.org/10.20431/2349-0349.0812006.

Copyright: (c) 2020 Authors. This is an open-access article distributed under the terms of the Creative Commons Attribution License, which permits unrestricted use, distribution, and reproduction in any medium, provided the original author and source are credited. 